attached to the grave posts of certain Algonkin tribes. This may be a further development of the thunder-bird idea.

Isolated cases have been noted of the finding of birdstones in the stonegrave burials of Tennessee, although the rarity of their occurrence would not make this an important factor in the canoe-prow theory.

RALPH H. Whitehead

Boston, Pennsylvania

\title{
Stoppers or Modeling Tools
}

In an article entitled Various Implements of Earthen Ware, Bureau of American Ethnology Annual Report 20, pages 35-36, illustration and mention are made of what the writer calls "trowel like objects of baked clay which are occasionally found in the central districts of the Mississippi valley."

He further states, "When placed stem downward these implements very closely resemble an ordinary form of toadstool. They have been regarded by some as stoppers for bottles but this was certainly not their normal use, and General Thruston is probably right in classing them as modeling tools for pottery making."

In my collection I have a pottery water bottle which was found with a stopper in place, shaped like a toadstool. These specimens were found at BoneBank, an ancient village site situated on the banks of the Wabash River, Posey County, Indiana.

I have heard questioned the opinion of General Thruston that these toadstool-shaped objects were not normally used as stoppers for bottles, and I should like to hear the opinion of some interested students.

Thomas J. Dillingham

Boonville, Indiana

\section{“Cell-Tempered" Pottery}

In American Antiquity, Vol. 1, No. 2, pp. 152-153, the Editor quotes a report on "cell-tempered" pottery by J. O. Everhart. Dr. Everhart points out the facts that calcite can be positively identified optically by refractive indices, that it is subject to solution by acidulated ground waters, and that the shape of the cavities in the pottery is such as would be formed by shell fragments but not by any of the other forms in which calcite occurs. As long as some material remains in the cavities it should, therefore, be a simple matter to prove whether or not the "cell-tempered" pastes are in reality only shell-tempered pastes which have been subject to leaching.

Dr. Everhart's suggestion regarding the original mineralogical composition of the shell, and his explanation of the spalling of the sherds call, however, for demonstration. The statement that "Most marine shells are composed largely of aragonite-" is insufficient basis for supposing that these particular shells 
were composed of that mineral. Presumably they were fresh-water shells. Milner ${ }^{89}$ reports that "Lamellibranchia vary, certain genera (e.g., Trigonia, Pinna, Spondylus, Unio, etc.) exhibiting an inner shell-layer of aragonite, the outer being of calcite; Ostrea, Pecten, etc., are entirely of calcite; otherwise many forms are composed of aragonite." Clearly the mineralogical form of the calcium carbonate in the particular kind of shell under consideration should be determined.

The suggestion is made that spalling was caused by the inversion of aragonite to calcite. The statement that "This alteration is accompanied by a volume increase of 10 to 15 per cent-" requires elucidation. If the increase in volume is calculated on the basis of the specific gravity of the two minerals, values of 7.9 and 8.5 per cent are obtained, taking the specific gravity of calcite as 2.714, and the extremes of aragonite as 2.93 and 2.95, as given in Dana's Textbook of Mineralogy. Rosenbusch ${ }^{90}$ gives a specific gravity of 2.714 for calcite and 2.937 for aragonite; Winchell ${ }^{91}$ and Larson ${ }^{92}$ both give 2.715 for calcite, and 2.94 for aragonite.

Available experimental data may not show conclusively how much pressure low-fired clay bodies will withstand. There is, of course, a direct relation between compressive strength and the temperatures of firing together with the refractoriness of the clay, but again the answer to the question is to be found by experimentation. When a clay body having the same materials and the same grain size and amount of temper as were used by the primitive potter is fired within the potter's temperature range, does it spall?

It is common knowledge that the calcination of calcium carbonate, and its subsequent hydration, which results in a $30 \%$ increase in volume, causes serious spalling. Thus heavy calcite tempering, overfired, will cause the complete crumbling of the vessel wall. The decomposition of calcium carbonate takes place over a considerable temperature range. It commences very slowly at a relatively low temperature, slightly above $600^{\circ} \mathrm{C} .{ }^{93}$ There is, therefore, always the possibility of partial calcination of the calcium carbonate to consider as an explanation of spalling.

The term "cell-tempered" or "hole-tempered" as applied to pottery is doubtless a convenient misnomer. It does, however, suggest a distinct class of material. If these specimens are only leached sherds of shell-tempered pottery, as Dr. Everhart seems satisfactorily to have demonstrated, the advisability of retaining the name might well be questioned. Observations as to the soil conditions under which this kind of pottery is found, of the varying degree of solu-

\footnotetext{
${ }^{89}$ Sedimentary Petrology, London, 1929, p. 309.

${ }^{90}$ Mikroskopische Physiographie

9l Elements of Optical Mineralogy

${ }^{92}$ Determination of the Nonopaque Minerals.

${ }^{93}$ Wilson, Ceramics, Clay Technology, pp. 154-155.
} 
tion of the material in the cavities, and comparison of the clay in this and shell-tempered pottery would seem pertinent to the study.

\author{
Anna O. Shepard \\ Santa Fe, New Mexico
}

\title{
Metallographic Study of Copper Artifacts
}

The clear exposition by Wilson and Sayre of the metallographic study of primitive copper work, American Antiquity, Vol. I, No. 2, pp. 109-112, must impress the archaeologist as presenting a precise and valuable means of extending our knowledge of this primitive industry. Although the archaeologist recognizes that the application of the method requires training in the microscopic study of opaque minerals, and that analyses should be undertaken by the specialist, he is none the less interested in the details of the technique and in the limits of its accuracy, in order that he may better judge the extent of its application to his problems. One would like to know, for example, more about the significance of twinning in copper. The following quotations suggest the need for further explanation:

"Twinning always shows that the copper has been mechanically worked and then annealed" (p. 111).

"This spearhead was hot-worked, at a bright red, about $800^{\circ} \mathrm{C}$., and thoroughly annealed after being worked. The evidence for these conclusions is: large, equiaxed grains, showing good annealing; twinning, indicating mechanical working" (pp. 111-112).

"This arrow-point was hot-worked, the work ceasing at about $500^{\circ} \mathrm{C}$, not followed by annealing. The evidence for this is the occasional twinning, the different sized grains, and the unequal axes of many of the grains" (p. 112).

"This axe was hot-worked, followed by good annealing, but at relatively low temperature, about $500^{\circ} \mathrm{C}$. The evidence for this is the equiaxed grains, with some twinning, with uniform grain size throughout, but with all grains small"' (p. 112).

"This nugget was heated, allowed to cool, and then cold-rolled. The grains are elongated, without twinning, proving that the metal was not annealed after having been worked" (p. 112).

The occasional twinning in a specimen that was hot-worked but not afterward annealed seems a contradiction of the general statement that twinning always shows that the copper has been mechanically worked and then annealed. But perhaps the effects of hot-working without subsequent annealing are comparable to cold-working followed by annealing. If so, how are the two methods of workmanship distinguished, by the shape of grains?

It would also be of particular interest to know how close is the correlation between size of grain and temperature of heating; if it is reported, for example, that an implement was "annealed at about $500^{\circ} \mathrm{C}$.," what are the limits above 